\title{
Vidas secas e a perspectiva de emancipação social
}

Barren Lives and the perspective of social emancipation

Bernard Herman Hess

Doutor em Literatura pela Universidade de Brasília. Professor de Literatura no curso de Licenciatura e Educação do Campo da Universidade de Brasília. bernard@unb.br

(D) https://orcid.org/0000-0003-3383-7387

Recebido em: 12/12/2018

Aceito para publicação em: 13/12/2018 


\section{Resumo}

Entre o narrador e os personagens de Vidas secas ocorre um espaço tenso de comunicação, espaço que expõe mundos desiguais, mas que compartilham a necessidade e a possibilidade do progresso humano, a uns, concedido, negado a outros; esses mundos se encontram na figuração literária de Vidas secas, para dar expressão àqueles que, em meio à seca, desejam vida, fartura, amor, progresso. Entre os próprios personagens ocorrem desníveis, sutis, mas que constituem a riqueza ou "astúcia" do real (Lenin); a partir dela, opera-se, dialeticamente, a superação histórica.

Palavras-chave: Graciliano Ramos. Vidas secas. Georg Lukács.

Realismo. Perspectiva

\section{Abstract}

Between the narrator and the characters of Barren Lives there is a tense space of communication, a space that exposes unequal worlds, but which share the necessity and possibility of human progress, conceded to some, denied to others. In Barren Lives these worlds are literarily figured to give expression to those who, in the midst of drought, desire life, abundance, love, progress. Among the characters themselves there are subtle mismatches, but they constitute the wealth or "cunning" of the real (Lenin); from it, the historical overcoming is operated, dialectically.

Keywords: Graciliano Ramos. Barren lives. Georg Lukács. Realism. Perspective 
"A classe dos proprietários e o proletariado representam a mesma auto-alienação humana. Mas a primeira classe se sente à vontade nesta alienação, por saber que a mesma é uma força que se exerce a seu favor e the proporciona a aparência de uma existência humana, ao passo que a segunda classe, a contrário, se sente anulada pela alienação e discerne em tal alienação a sua própria impotência, bem como a realidade de uma existência inumana."

K. Marx

“(...) ser sensivel é ser padecente. O homem enquanto ser objetivo sensível é, por conseguinte, um padecedor, e, porque é um ser que sente seu tormento, um ser apaixonado. A paixão é a força humana essencial que caminha energicamente em direção ao seu objeto."

K. Marx

A perspectiva enquanto elemento integrante da obra literária tem sido apontada por parte da crítica marxista como questão nodal da escrita realista. A arte e o realismo crítico atual, após a derrocada das primeiras tentativas revolucionárias por parte do proletariado de pôr termo à ordem social burguesa, se encontram agora diante de situações historicamente novas, e que exigem clareza teórica. Diante disso, indaga-se novamente sobre o papel da arte, numa nova quadra histórica: ela deve tomar ou não partido diante da ameaça do crescente aprofundamento da barbárie? Ela deve opinar se há ou não perspectiva para além da ordem da exploração do homem pelo homem? E como a arte e a literatura podem ou devem figurar as angústias e esperanças dos homens, os seus desejos de recusar e superar formas de vida inumanas? Encerrado nos estreitos e objetivos limites da reificação, os homens serão ainda capazes de tomar consciência da possibilidade da emancipação? Num momento em que rememoramos a dramática atualidade das contribuições teóricas de Karl Marx, e em que uma obra como Vidas secas, aos 80 anos, ainda suscita amplo debate crítico, o que significa para nós a noção da perspectiva histórica de progresso humano e como ela pode estar contida e plasmada na obra literária?

A geração de escritores modernistas no Brasil, sobretudo na década de 30, buscou posicionar-se diante de novos fatos históricos, a vitoriosa Revolução russa e a possibilidade de edificação de uma nova forma social e econômica que o atraso brasileiro exigia. Surge daí o debate sobre o romance proletário e suas realizações estéticas, debate travado ao longo desta década por via de crônicas, resenhas e também por meio dos próprios romances publicados no período. Vidas secas (1938), de Graciliano Ramos, é, em nossa opinião, a obra que mais tipicamente incorpora esse debate e na qual a relação 
dialética entre as condições sociais objetivas e a possibilidade subjetiva da emancipação se elabora, artisticamente plasmado, nas atitudes e nos pensamentos das personagens literárias.

\section{A perspectiva no realismo crítico: negação e superação em Vidas secas.}

A questão da perspectiva aparece, não por um acaso nessa mesma quadra histórica do século XX, como um problema estético dentro dos romances do modernismo brasileiro da geração de 30. Durante toda a década, os escritores brasileiros desenvolveram um esforço intenso e amplo em tematizar a vida do proletariado urbano e rural. Aliás, desde a Semana de Arte Moderna de 1922, evento que já recebia os influxos mais decisivos da Revolução Russa vitoriosa e das assim chamadas vanguardas europeias, a perspectiva da ruptura com a velha ordem do capitalismo mercantil se colocava no horizonte da produção artística brasileira, e estava implícita nos vários manifestos publicados durante o período do movimento modernista.

Mas foi sobretudo durante o período dos anos 30 que se caracterizaria como 'romance proletário', que a representação literária das massas pobres e espoliadas do campo e da cidade passou a ocupar o centro da atividade dos escritores nacionais. Logo romancistas como José Lins do Rego, Dyonélio Machado, Érico Veríssimo, Cyro dos Anjos, Raquel de Queiroz, Amando Fontes entre outros ganharam público leitor relativamente expressivo para os parâmetros da época. Mas talvez Jorge Amado e Graciliano Ramos fossem os expoentes mais paradigmáticos dessa geração, que Antonio Candido definiu como portadora da "consciência catastrófica do atraso". (CANDIDO, 1989, pp. 140-162). $\mathrm{Na}$ verdade, além dos autores acima citados, formou-se, nessa década esteticamente bastante produtiva, um verdadeiro exército de literatos mais ou menos talentosos, muitos ligados direta ou indiretamente ao pensamento proletário e socialista.

Escolhemos, para a nossa análise, a novela Vidas secas (1938), de Graciliano Ramos, por constituir ela mesma uma espécie de síntese do esforço empenhado pela geração de 30 na busca da forma mais apropriada de representação do outro de classe.

Nossa investigação pretende partir da própria fatura literária do romance. A perspectiva se apresenta no tecido narrativo, na particularidade artística da obra; nele está contido, por si só, o empenho dos homens pela transformação gradual da vida, por um mundo outro, o mundo em que a emancipação universal seja possível. Em segundo lugar, busco demonstrar que, em Vidas secas, o mundo emancipado não é proposto pelo escritor como tese apriorística, ou como utopia ideal, mas compreendido como necessidade e possibilidade pelas próprias personagens de ficção. Ou seja, a perspectiva contida na obra 
não é mera abstração; ela é a mesma da relação dos homens com as suas necessidades objetivas e com o reconhecimento das possibilidades de um mundo novo. Portanto, o mundo outro, desejado e necessário, deriva das contradições cotidianas das personagens, é negação dialética, é superação parcial e gradativa do objeto ou mundo negado. Superação, no sentido formulado por Hegel, não é negação absoluta; ela é sempre relativa. A superação dialética é aquela que supera, mas também conserva; aliás, mais conserva do que supera. O substantivo Aufhebung deriva do verbo aufheben, que é usado por Hegel, no duplo sentido, assim como a palavra ocorre no alemão: por um lado, significa ultrapassar, superar, transpor, por outro, guardar, manter, conservar. Do mundo em negação, conserva-se grande parte; parte menor é superada. Após sucessivas superações parciais, o objeto é negado de modo profundo, substantivo.

Em Vidas secas, a realidade vivida pelas personagens permite que apenas pequenos passos sejam dados, que pequenos objetos do cotidiano sejam transformados. E são as próprias personagens que agem e reivindicam transformações, mas só na medida em que seus limites objetivos e subjetivos, sempre bastante estreitos, o permitem. Este é o problema central para a literatura realista: a perspectiva de superação deverá ser sempre modesta. Ela constitui, como diz Lenin, a realização apenas do próximo elo da cadeia, não mais que isso. Lukács, em "O problema da perspectiva", afirma que “(...) a perspectiva só é autêntica e concreta quando surge das tendências de desenvolvimento dos indivíduos representados na obra de arte - e não quando é justaposta como verdade social objetiva a determinados homens que têm com ela apenas uma tênue ligação pessoal." (LUKÁCS, 2010, p. 288).

Mais adiante, o esforço teórico do pensador húngaro procura reconectar o realismo socialista - para que tenha eficácia estética - ao grande e verdadeiro realismo crítico burguês, contrapondo-se às influências do naturalismo e das "técnicas de vanguarda" na produção literária dos escritores socialistas. E a questão nodal para a literatura socialista conseguir se livrar dos vícios de um utopismo simplista e idealista, inerente ao "romantismo revolucionário", será sempre o de saber quanto de perspectiva deve ser representado pela obra, o quanto suas personagens são capazes de avançar, em suas atitudes e pensamentos. Leia-se o trecho seguinte, no mesmo ensaio:

Pode-se afirmar que, no interior do realismo crítico, este é um caso excepcional; sobretudo na evolução posterior deste realismo [na fase decadente], existem romances que não possuem perspectiva no sentido indicado. O realismo socialista, ao contrário, deve ter uma perspectiva, sob pena de não ser socialista. O problema consiste em quanto desta perspectiva deve ser figurado. Logo se dirá que a nossa perspectiva é o socialismo. É verdade; mas, por um lado, o socialismo é um conceito geral, e, por outro, uma expressão que designa todo um período, o qual, em face de homens e destinos individuais, aparece como uma abstração pura, como um ideal 
puro. Se refletirmos sobre este fato, tornar-se-á claro o critério para determinar quanto de perspectiva pode suportar a caracterização individual dos personagens de um romance, ou seja, a parte de perspectiva exigida imperiosamente por este modo de representar a individualidade e a tipicidade dos homens que aparecem efetivamente nestas obras. E, quando consideramos desse ponto de vista as grandes obras do realismo socialista, constatamos - talvez com certa surpresa - que sua perspectiva imediata é bastante modesta. (LUKÁCS, 2010, pp. 288-289).

O que verificamos em Vidas secas? Nos seus elementos compositivos fundamentais, dos quais deriva organicamente a subjetividade das personagens, compreende-se como essas personagens tomam consciência de que fazem parte de um processo histórico maior, das transformações em devir; mas o fazem sempre dentro dos limites objetivos colocados pela realidade, e dentro, também, dos seus limites subjetivos, de máxima consciência possível. Por isso a perspectiva é sempre modesta, a possibilidade de superação se dá sempre na seguinte proporção: há mais conservação do que superação. $E$ trata-se sempre de superações reais. A composição dos elementos sociais e individuais ganha vida - e sentido histórico - só quando ela se concretiza na figuração de personagens singulares que, em atitudes e situações singulares, agem ou se posicionam diante dos seus desejos.

A perspectiva, é claro, modifica-se nas diversas obras, de acordo com a época que elas representam e com os personagens que nelas atuam. Mas é sempre uma perspectiva imediata relativamente modesta. Por quê? Porque mesmo o romance mais importante e de mais vasto conteúdo (...) abarca somente uma etapa da evolução; assim, sua perspectiva só pode iluminar, concretamente, o próximo passo, o próximo elo da cadeia, como diria Lenin. (LUKÁCS, 2010, p. 289)

A definição acima serve para se pensar, mutatis mutandis, como cada um dos nossos escritores, nos anos 30, buscou integrar a perspectiva socialista em suas obras. Mais adiante, as posições do crítico húngaro ficam ainda mais claras:

E se o escritor vai além disso, terá de construir, na maior parte dos casos, abstrações acima de seus personagens; ou então, como veremos a seguir, terá de violentar os seus personagens, impondo-lhes uma perspectiva que formula como pensador, como bom socialista. Deste modo, os personagens são deformados e convertidos em abstrações. (LUKÁCS, 2010, p. 289)

Sabe-se que alguns, sobretudo aqueles que mais diretamente estavam sob influência ou mesmo pressão do PCB, se esforçavam para seguir exatamente os preceitos da escrita "proletária" defendidos por Zdhanov e Stalin, o "romantismo revolucionário". Preceitos que foram combatidos por Lukács internamente, combate que, como sabemos, teve que se dar sob as vestes de citações protocolares, tais como, "já disseram Lenin e Stalin,...". As passagens aqui citadas de Lukács, livres desses disfarces, são de "O problema 
da perspectiva", escrito em 1956, ano em que vieram à tona discursos oficiais denunciando, além de outras coisas, os desvios teóricos do stalinismo.

Graciliano, do outro lado do oceano, mas antenado nos debates políticos e artísticos do mundo, conhecia muito bem a tradição literária russa, e tomou posição diante das novas produções literárias da Rùssia revolucionária. Não estava de acordo com os métodos didáticos do Proletkult, e dos modelos propostos pela cartilha zdhanovista para uma literatura "revolucionária"; recusava-se, portanto, a aceitar como válidas aqui as fórmulas inculcadas no além-mar. Graciliano decidiria se filiar ao partido só em 1945, ano em que era publicado Infância. Nos anos seguintes, teve que ouvir críticas rasteiras aos seus romances, sobretudo $S$. Bernardo e Vidas secas. Na opinião de alguns da alta direção do Partido, Fabiano deveria ter matado o soldado amarelo. Sofreu pressões durante a escrita de Memórias do Cárcere, mas recusava-se habilmente: era incapaz de escrever de outro modo.

Vários escritores daquela época que haviam se filiado ao Partido, sofreram pressões e cobranças vindas da direção do Partido. Mas, felizmente, a produção literária de escritores de talento, como Jorge Amado, seguiria, em grande parte, um destino diverso daquele traçado pela referida cartilha. O diálogo entre Graciliano Ramos e a sua geração de romancistas é rica enquanto traz ao debate geral o modo como esses escritores poderiam retratar o nosso atraso, como poderiam, esteticamente, interpretar a miséria local. Darei apenas um exemplo. Em uma resenha (RAMOS, 1971, pp.107-111) escrita no ano em que sai Suor, de Jorge Amado, Graciliano analisa com atenção aspectos diversos do romance, e, no geral, tece elogios à obra, filiando-a à geração que produziu, no início da década, obras que se destacam pela representação corajosa, desprovida de preconceitos da realidade.

Os escritores atuais foram estudar o subúrbio, a fábrica, o engenho, a prisão da roça, o colégio do professor cambembe. Para isso resignaram-se a abandonar o asfalto e o café, viram de perto muita porcaria, tiveram coragem de falar errado, como toda gente, sem dicionário, sem gramática, sem manual de retórica. Ouviram gritos, pragas, palavrões, e meteram tudo nos livros que escreveram. Podiam ter mudado os gritos em suspiros, as pragas em orações. Podiam, mas acharam melhor pôr os pingos nos ii. O Sr. Jorge Amado é um desses escritores inimigos da convenção (...) (RAMOS, 1971, p. 108)

Se Suor é um romance de grandes qualidades, sobretudo pelo apego à verdade dos fatos, irá apresentar também alguns sinais daqueles problemas que resultariam da ingerência da política cultural do PCB. Na mesma resenha, Graciliano identifica um desses problemas na obra de Jorge Amado: 
O autor falha, porém, nos pontos em que a revolta da sua gente deixa de ser instintiva e adota as fórmulas inculcadas pelos agitadores. As figuras de Álvaro Lima, do anarquista espanhol, do comunista judeu, não têm relevo, apesar de serem as mais trabalhadas. Quando elas aparecem, o livro torna-se quase campanudo, por causa das explicações, das definições, que dão aos três personagens um ar pedagógico e contrafeito. O prêto Henrique, as moças do terceiro andar, o mendigo, os fregueses da bodega do Fernandez, as meretrizes, exprimem-se ingenuamente. Chega um desses homens, traduz a fala em língua política, de cartaz - e sentimos um pouco mais ou menos o que experimentamos quando vemos letras explicativas por baixo de desenhos traçados a carvão nas paredes. Não nos parece que o autor, revolucionário, precisasse fazer mais que exibir a miséria e o descontentamento dos hóspedes do casarão. A obra não seria menos boa por isso. (RAMOS, 1971, p.110)

Este debate quer discutir o aspecto central do modo de representar com realismo a face miserável do processo modernizador, agravada com a revolução de 1930. No nordeste brasileiro, a introdução do maquinário agrícola moderno produziu, não um relativo e provisório progresso social, como nos países centrais, mas um atraso devastador.

A defesa que Graciliano faz da literatura realista não está preocupada com a nomenclatura. Apenas insiste que os romancistas mantenham o vigor, a verossimilhança e a tensão orgânica entre sujeito e objeto, para conseguir exibir personagens reais, em situações reais da vida. Aquele romance vigoroso que predominava nos primeiros anos da década de 30 sofria guinada decadente, perdia sua força de representação. Graciliano cobrava dos escritores da sua época que exibissem homens e atitudes reais: precisavam explicar a origem e formular literariamente o processo de formação das atitudes, dos pensamentos e sentimentos, da angústia, do desespero, da loucura dos personagens em seus romances. A ação objetiva dos personagens na vida cotidiana devia ser o ponto de partida na figuração dos trágicos destinos humanos. Graciliano estava preocupado, como se vê em inúmeras crônicas e resenhas de Linhas tortas (RAMOS, 1971) e Garranchos (RAMOS, 2012), com o futuro do romance brasileiro, com sua força estética, de revelar as razões das condições de miséria vividas pelo povo naquela região. Em "O fator econômico no romance brasileiro", (RAMOS, 1971), aponta para os problemas da literatura produzida naqueles anos, e para a necessidade de ela explicar objetivamente um fato subjetivo:

Para sermos completamente humanos, necessitamos estudar as coisas nacionais, estuda-las debaixo para cima. Não podemos tratar convenientemente das relações sociais e políticas se esquecemos a estrutura econômica da região que desejamos apresentar em livro.

Quando um negociante toca fogo na casa, devemos procurar o motivo deste lamentável acontecimento, não conta-lo como se ele fosse apenas um arranjo indispensável ao desenvolvimento da história que narramos. Se um cavalheiro mata os filhos e se suicida é bom não afirmarmos precipitadamente que ele endoideceu: vamos tomar informações, tentar saber em que se ocupava o homem, que ordenado 
tinha, quanto devia à dona da pensão. Geralmente ninguém queima o negócio nem se suicida à toa.

Dizer que um ato reprovável foi praticado porque o seu autor obedeceu ao impulso irresistível é pouco: isto satisfaz o leitor de notas policiais. Seria razoável que tentassem descobrir a causa do impulso, não se limitassem a apresentar-nos o comerciante incendiário como desonesto, o assassino como um sujeito perverso ou louco.

Admitimos sem esforço a desonestidade e a loucura mas precisamos saber porque elas existem, não queremos que sejam presentes do escritor as personagens. $O$ romancista não é nenhum deus para tirar criaturas vivas da cabeça.

Romanceando por exemplo o crime e a loucura, está visto que ele deve visitar os seus heróis na cadeia e no hospício, mas, se quiser realizar obra completa, precisa conhece-los antes de chegar aí, acompanha-los na fabrica ou na loja, no escritório ou no campo de plantação. Necessariamente o ofício dos seus homens deve ter contribuído para que as coisas se passassem desta ou daquela forma.

É intuitivo que o negociante deitou fogo ao estabelecimento porque seus lucros se reduziam. Digam-nos como se operou a redução.

E o indivíduo que matou os filhos e deu um tiro na cabeça? De que se alimentava esse malvado, a que gênero de trabalho se dedicava? Certamente ele é um malvado. Mas a obrigação do romancista não é condenar nem perdoar a malvadez; é analisa-la, explicá-la. Sem ódios, sem idéias preconcebidas, que não somos moralistas.

Estamos diante de um fato. Vamos estuda-lo friamente.

Parece que este advérbio não será bem recebido. A frieza convém aos homens de ciência. O artista deve ser quente, exaltado. E mentiroso.

Não sei por quê. Acho que o artista deve procurar dizer a verdade. Não a grande verdade, naturalmente, pequenas verdades, essas nossas conhecidas. (RAMOS, 1971, pp. 326-327)

Vidas secas, o último de quatro romances, é o primeiro que parte para a representação do outro de classe, do sertanejo iletrado, que se situa na condição oposta ao do homem letrado, do intelectual e escritor. Graciliano se coloca nesta obra um novo desafio, penetrar a alma de homens que não pertencem à sua classe. Derivar da situação objetiva do ofício de um sertanejo reflexões e sentimentos, perscrutar a alma de homens brutos, esta era, para ele, tarefa extremamente difícil. O escritor não é um trabalhador rural, não exerce um ofício braçal; mas, ao mesmo tempo, é o dever do intelectual e do literato, figurar aqueles que representam multidões que perambulam pelo sertão ou habitam os subúrbios das grandes cidades, esquecidos e abandonados pelo projeto modernizador elitista de 1930.

Por isso, muitos críticos chamam a atenção do leitor para a razão e o papel do narrador em terceira pessoa. De um lado, há entre o narrador e as personagens de Vidas secas um espaço tenso de comunicação que pertence a mundos desiguais, embora não antagônicos; mundos que se encontram com ênfase particular na figuração literária. Em termos gerais, ocorre o encontro do mundo do homem letrado como o mundo do iletrado. 
Mas também encontramos desníveis entre as próprias personagens; embora sutis, eles são fundamentais para o desenvolvimento das superações singulares dentro da dialética geral da superação histórica. Por outro lado, o leitor é seduzido a ver justificada a condição alienada e limitada das personagens daquele mundo humano e de dela deduzir a impossibilidade da sua superação. Mas, quase imperceptível, deriva dela, organicamente, a perspectiva da justiça social, como direito universal, mesmo que ela se dê na forma de pequenas conquistas, algumas apenas sonhadas, mas no horizonte do possível.

O escritor e, de modo muito particular, o narrador estão diante de personagens a serem perscrutadas, serem reveladas ao público leitor, mas, necessariamente, dentro do mundo específico ao qual pertencem, o mundo que percebem objetivamente, condições objetivas que desejam superar, mundo que desejam, objetivamente, ver transformado. Para isso o escritor assume o seu lugar à distância e irá criar um narrador que recebe, das personagens, uma procuração para representá-las (CANDIDO, 1999). O narrador recebe poderes para representar literariamente (pelo seu domínio das letras) cada um dos viventes no romance. Mas este narrador é também alguém que mantem relativa distância das personagens, ora se aproxima, ora se distancia, jamais se confunde com os seus representados.

\section{Vidas secas: entre o mundo natural e o mundo humano}

Na novela de Graciliano Ramos, cada uma das personagens protagonistas, de Fabiano a Baleia, é individualizada, representada por dentro, perscrutada. Mas o que nos interessa aqui pesquisar é como todos eles, de modo geral, percebem o mundo que os rodeia, que os oprime, e em que medida lutam para superá-lo. Em um estudo mais detalhado, notase que todos os membros da família, inclusive a cachorra Baleia, tem consciência do mundo natural opressivo e do mundo social injusto. Em sua condição alienada, as leis do mundo natural assim como as do mundo social são registradas como algo determinado por forças superiores, inexplicáveis, inevitáveis.

Fabiano, no capítulo "Mudança", quando conduz a família pelas veredas da catinga, "num cotovelo do caminho, avistou um canto de cerca". Este canto de cerca é, após dias, a primeira imagem que quebra a permanência do mundo natural massacrante, mundo que quase faz o pai abandonar o menino mais velho; surge, repentinamente, no campo de visão do retirante, um canto de cerca, ou seja, abre-se a possibilidade de um espaço 
humanizado: "encheu-o a esperança de achar comida, sentiu desejo de cantar. A voz saiuIhe rouca, medonha. Calou-se para não estragar força." (RAMOS, 1969, p. 46) 1

Em poucas linhas, dois mundos se encontram: ao mundo natural da catinga, inóspito, opressivo, aquele mundo percorrido por dias, se antepõe uma cerca. Bem pensado, não se trata de uma simples cerca, mas de um canto de cerca. Uma cerca representaria a separação entre duas propriedades; um canto de cerca simboliza o fim de uma terra inabitável, inóspita, e o início de algo que foi cercado, onde algo de valor é guardado. Fabiano e a família terminam, provisoriamente, a jornada que atravessou um espaço geográfico sem quaisquer traços visíveis de civilização. Chegaram a um local onde a vida pode ser possível; apresenta-se aqui um outro tipo de mundo, onde algo foi transformado pelo homem, no qual há marcas de vida social, de vida possível ao homem, um mundo em que ficaram registrados alguns sinais de civilização. Termina o sofrimento da travessia de um meio natural inóspito para iniciar-se uma etapa em que a vida humana poderá acontecer. Surge a esperança de haver comida. Fabiano se enche de coragem, involuntariamente passa a cantar. Cala-se, porém, "para não estragar força". O parco sinal de civilização inspira esperança, mas a experiência do retirante manda que poupe suas forças físicas.

Fica assim apresentada a oposição central em torna da qual giram os episódios narrados que determinam os destinos da família do vaqueiro. São homens que buscam viver, e viver como homens, em segurança e conforto material, em condições de desenvolverem os sentidos humanos, a possibilidade de fruição da vida. A possibilidade do amor, do humano, se liga diretamente, como veremos agora, a condições materiais criadas pelo ser social, pelo progresso.

Tomarei como contraponto e também como análise complementar à observação inicial feita, o problema trabalhado com grande frequência pela crítica, que investiga as questões suscitadas pela cama de Sinha Vitória. Na verdade, sinha Vitória deita-se, mais uma vez, numa cama de varas.

Pensou de novo na cama de varas e mentalmente xingou Fabiano. Dormiam naquilo, tinham se acostumado, mas seria mais agradável dormirem numa cama de lastro de couro, como outras pessoas.

Fazia mais de um ano que falava nisso ao marido. Fabiano a principio concordara com ela, mastigara cálculos, tudo errado. Tanto para o couro, tanto para a armação. Bem. Poderia adquirir o móvel necessário economizando na roupa e no querosene. Sinha Vitória respondera que isso era impossível, porque eles vestiam mal, as crianças andavam nuas, e recolhiam-se todos ao anoitecer. (VS, pp. 77-78).

${ }^{1}$ Todas as citações diretas do romance Vidas secas terão como referência RAMOS, Graciliano. Vidas secas. São Paulo: Martins, 1969. Desse modo, daqui em diante, nas citações, serão indicadas apenas com a sigla VS e as páginas dessa edição. 
Sinha Vitória lembra-se também, no decorrer do seu solilóquio - um devaneio amargo sobre as dificuldades e as remotas possibilidades de obterem o objeto sonhado que havia pedido a Fabiano que substituísse uma das varas: "bem no meio do catre havia um nó, um calombo grosso de madeira". Mas, na verdade, desejava deitar-se sobre uma cama de verdade, "como outras pessoas"; assim dá a entender que usufruir de condições de vida dignas não era um disparate, algo impossível; era real, era possível, havia pessoas que viviam assim, suas conhecidas. O leitor também irá se lembrar que Sinha Vitória se refere a este tipo moderno de cama como a algo do que ela mesma tinha conhecimento. Há repetidas referências ao Seu Tomás da bolandeira. Sabia, pois tinha visto de perto, que o objeto sonhado existia. Tratava-se de uma cama de verdade: "Ali podia um cristão estirar os ossos".

Assim como deseja superar a condição animal, de seres submetidos às determinações das forças naturais, também ela deseja desvencilhar-se desse jugo nos demais aspectos da vida. Fabiano sugere economizarem em roupa e querosene para adquirirem a cama. Sinha Vitória protesta: "as crianças andavam nuas, e recolhiam-se todos ao anoitecer" (VS, pp. 77-78). "E o costume de encafuar-se ao anoitecer não estava certo, que ninguém é galinha" (VS, p.82).

Logo, as divagações sobre a cama, que constituem o mote central do capítulo, têm caráter simbólico, são uma espécie de metonímia da situação mais geral da família do vaqueiro. Próximos à natureza, mas ao mesmo tempo dela afastados por uma relação de trabalho alienado, as personagens de Vidas secas parecem constituir símbolos daquele ser social que não só luta pela sobrevivência, mas que também, no estreito limite da sua ação individual, procura imputar ao processo social uma transformação necessária, um pequeno passo no processo da evolução histórica-social. É nesse sentido que se pode dizer que a oposição meio natural - meio social é aqui a questão central: natureza inóspita e mundo humanizado pelo trabalho. E, se entendido do ponto de vista ontológico, trata-se de uma oposição em perspectiva histórica, pois o mundo social é natureza teleologicamente transformada pelo trabalho.

A atual cama de Sinha Vitória, de varas, é necessariamente parte do seu passado, do passado que é recordado e que igualmente é legado ao leitor por via do narrador/procurador. Mas esse passado, e o modo de vida a ele associado, parece ter atingido seu auge, seu limite; as personagens chegaram a um ponto em que notam ser possível e necessária uma pequena inflexão na direção de uma vida melhor. Mas trata-se apenas de um pequeno passo, de um possível pequeno passo real.

O princípio artístico da escrita realista se realiza quando o movimento histórico é captado no momento presente e na vida cotidiana objetiva, em sua infinita riqueza e 
"astúcia" (Lenin). A perspectiva de superação histórica deve ser, por isso mesmo, algo concreto, organicamente ligada ao real presente, não apenas uma ideia utópica, o sonho de um futuro outro. O mundo de Vidas secas não é algo fictício, nem cabe dentro dele espaço para a propaganda de uma outra ordem social que não derive organicamente da ordem social presente. As personagens da novela estão submetidas a limites que têm correspondência com o mundo que habitam como homens singulares. Os passos dados por elas nesse microcosmo têm proporções reais, permitidos pelos limites do mundo real. Quando Marx afirma que um passo real do movimento vale mais do que o melhor programa formulado, pode se dizer também que a obra literária tem valor e eficácia "precisamente quando traduz para a forma um passo real dado pelo movimento." (LUKÁCS, 2000, 291) A perspectiva que existe plasmada na forma de Vidas secas é a perspectiva de homens reais em situações reais. "A perspectiva só é autêntica e concreta quando surge das tendências de desenvolvimento dos indivíduos representados na obra de arte - e não quando é justaposta como verdade social objetiva a determinados homens que têm com ela apenas uma tênue ligação pessoal" (LUKÁCS, 2010, 288)

Recordemos uma passagem em que a escrita revela as reflexões que Sinha Vitória faz em seu monólogo interior:

Outra vez Sinha Vitória pôs-se a sonhar com a cama de lastro de couro. Mas o sonho se ligava à recordação do papagaio, e foi-lhe preciso um grande esforço para isolar o objeto do seu desejo.

Tudo ali era estável, seguro. O sono de Fabiano, o fogo que estalava, o toque dos chocalhos, até o zumbido das moscas, davam-lhe sensação de firmeza e repouso. Tinha de passar a vida inteira dormindo em varas? Bem no meio do catre havia um nó, um calombo grosso de madeira. E ela se encolhia num canto e o marido no outro, não podiam estirar-se no centro. A princípio não se incomodara. Bamba, moída de trabalho, deitar-se-ia em pregos. Viera, porém, um começo de prosperidade. Comiam, engodavam. Não possuíam nada: se se retirassem, levariam a roupa, a espingarda, o baú de folha e troços miúdos. Mas iam vivendo, na graça de Deus, o patrão confiava neles - e eram quase felizes. Só faltava uma cama. É o que aperreava Sinha Vitória. Como já não se estazava em serviços pesados, gastava um pedaço da noite parafusando. E o costume de encafuar-se ao escurecer não estava certo, que ninguém é galinha. (VS, p. 82)

A construção de Vidas secas traz certa liberdade com relação à verossimilhança. Como num painel, despreza os traços tradicionais, regionalistas da narrativa romanesca prosaica. Compõem o conjunto a partir de partes já por si autônomas. Tece um diálogo entre o narrador (letrado, racionalista, politizado) e o personagem (iletrado, místico e mágico, alienado), fazendo com que os universos dos dois se contaminem mutuamente. Fabiano fala por meio da fala do escritor. O narrador, aparentemente neutro, se envolve - por via 
do discurso indireto livre - nas ações narradas, e, assim como a personagem, tampouco pode apontar as saídas para a condição de opressão em que todos vivem.

\section{O dilema do nó na cama de varas}

O dilema do nó encerra, na verdade, por assim dizer, a questão nodal da obra e da própria literatura brasileira da época. Graciliano dialoga, em minha opinião, com as posições estéticas e políticas da época e da sua geração de escritores. Vidas secas avança bastante nesse debate: por um lado, dá a ver que não cabe a representação literária caricatural, pitoresca, do nosso trabalhador rural, como se ele vivesse resignado diante do mundo opressivo, esboçando mero protesto contra ele, aceitando-o e adaptando-o, submetendo-o a pequenas e insignificantes reformas (a retirada do incômodo nó).

Por outro lado, superada a concepção reformista, opõe-se igualmente à concepção esquerdista, fatalista, esquemática. Para a esquerda da época, a literatura deveria plasmar um país e um povo decidido a desencadear um processo insurrecional. Graciliano não seria perdoado por permitir, por exemplo, que, em Vidas secas, o personagem Fabiano se acovardasse e fraquejasse diante do soldado amarelo, que se revelasse um fraco e não matasse aquele representante do governo. Mas para conceber corretamente esta questão, será necessário pensar de modo mais amplo o problema da figuração literária da perspectiva e das possibilidades da utopia concreta na obra realista e, em particular, na novela Vidas secas.

O realismo não concebe a arte como reflexo das ideias, nem contrapõe o fenômeno à essência. A obra realista busca a essência no fenômeno e o fenômeno da relação orgânica com a essência. A forma criada pelo artista é, certamente, inventada (por isso Lukács a chama de segunda imediatez), mas é igualmente verdade que ela tem a função de colocar em evidência o dinamismo das formas objetivas da realidade social representada. 0 conteúdo da arte não está apenas na objetividade do mundo real. As estruturas sociais de determinadas condições históricas são o ponto de partida concreto para o escritor, mas elas são, como disse Marx, não "a única causa ativa e todo o resto somente efeito passivo". (MARX, 2004, 139).

A tradição crítica marxista, portanto, se opõe à ideia de que o mundo é um caos informe e de que a forma literária é simplesmente "posta" pelo artista, é por ele criada arbitrariamente. Carlos Nelson Coutinho, no ensaio "Graciliano Ramos"2, de 1965 , texto basilar para a tradição marxista, entende que o processo social traz consigo formas

2 Coutinho, Carlos Nelson. "Graciliano Ramos". In: Literatura e Humanismo. Rio de Janeiro: Civilização Brasileira, 1967. 
prévias, inerentes à vida prática cotidiana. A perspectiva histórica e humanista já existe nas malhas dessa "objetividade das formas", formalizadas no tecido narrativo da obra literária. Segundo Coutinho, também Graciliano construiu seus romances sobre as formas objetivas da vida, dando-lhes a elaboração apropriada, com a intenção de figurar a essência dinâmica da história, ou seja, da forma social objetiva.

De um modo geral, ocorre - na obra romanesca de Graciliano Ramos - uma tensão dialética, organicamente assimilada, entre os narradores e as personagens narradas. Tensão que cria o poder de estabelecer, por meio das narrativas, conexões estruturais entre as origens dos dramas humanos e a percepção delas dentro de uma perspectiva totalizadora e progressiva, que irrompe em meio ao fluxo de consciência das personagens. A perspectiva se coloca, deste modo, para as personagens, na medida em que percebem um horizonte mais amplo e humano diante das suas lutas diárias mais mesquinhas. Mesmo que a narrativa tenha uma estrutura aparentemente circular, nota-se, após análise mais atenta, que ela evolui, que ela se constrói progressivamente. Há uma evolução significativa entre "Mudança" e "Fuga". Se há, como afirma Candido, uma identidade entre as situações de início e fim da novela, essa identidade se dá no campo meramente objetivo3. Do ponto de vista subjetivo, todas as personagens (inclusive Baleia, ao morrer, deseja acordar num mundo melhor) ganharam determinado grau de consciência, limitado, mas decisivo para se munirem de vontade para a retomada daquela eterna peregrinação. Em torno de um eixo, há uma acumulação entre os fatos imediatos e os fatos do passado recente; no campo do futuro mais próximo, colocam-se pequenas mudanças concretas, possíveis e necessárias.

Um crítico importante da obra do romancista, Benjamin Abdala Junior (1999), define como questão central da produção literária do autor o seu caráter ontocriativo. Lembra que a literatura é atividade humana histórica, práxis. Para ele, além da representação concreta da realidade, dá-se a participação ativa do próprio leitor. Assim, o escritor estabelece uma comunicação de reciprocidade com o leitor, através da qual o sujeito-leitor passa a reconhecer o seu mundo alienado e o seu estado de passividade, capacitando-o a quebrar com a imobilidade. Em Vidas secas, obra de estrutura narrativa peculiar - o foco narrativo em terceira pessoa e a adoção do discurso indireto livre -, a força ideológica do autor se coloca dialeticamente entre os heróis e o narrador, sendo portador da "máxima

\footnotetext{
3 No ensaio "Ficção e confissão", Candido enxerga Vidas secas como romance que "começa por uma fuga e acaba com outra." E conclui que o romance: "decorre entre duas situações idênticas, de tal modo que o fim, encontrando o princípio, fecha a ação num círculo." Mas Candido, em outro lugar do mesmo ensaio, ressalta que há uma diferença entre a situação objetiva do meio hostil que os cerca e oprime e o estado de alma das personagens: “(...) solda no mesmo fluxo o mundo interior e o mundo exterior. Em nenhum outro livro é tão sensível quanto neste a perspectiva recíproca, referida acima, que ilumina o personagem pelo acontecimento e este por aquele". CANDIDO, Antonio. "Ficção e confissão". In: Ficção e confissão. Rio de Janeiro, 1999.
} 
consciência possível" (GOLDMANN, 1976). Mas, se existe a tensão dialética entre autor e leitor, ela só exerce seu efeito na medida em que é resultado do processo ontocriativo entre as personagens e delas consigo mesmas, como apontamos acima. O que se torna sensível e apreensível para o leitor na obra é, por exemplo, a própria experiência de Sinha Vitória com relação ao objeto cama. A experiência de se deitar sobre uma cama de varas durante um significativo período da sua vida se encontra em defasagem em relação à agora próxima perspectiva/possibilidade de se deitarem numa cama com lastro de couro. Agora a possibilidade do encontro com Fabiano, a de expressar livremente seu amor ao ser humano mais próximo, até aqui impedido de acontecer, é quase real. $\mathrm{O}$ amor e o conforto material são valores e conquistas humanas; Sinha Vitória ganhou a consciência de que também tem direito a eles. Que também é gente. Mas a tensão entre autor e leitor na comunicação, que tem como objetos de análise personagens que agem, pensam, desejam, se estabelece necessariamente em relação ao processo histórico em desenvolvimento. A cama com lastro de couro, feita de madeira talhada com ferramentas como a enxó, formão etc. pressupõe experiência humana acumulada pelo trabalho. Sinha Vitória, à sua maneira, toma consciência de que eles também têm direito ao objeto, conquista da humanidade.

A remoção da vara com o nó representaria a desistência de um pequeno projeto em sua vida, significaria a resignação diante do mundo hiper-determinado pelas forças obscuras do meio natural e das forças opressivas próprias do mundo da propriedade privada e do privilégio aos bens de consumo; enfim, a remoção do nó significaria a aceitação da vida humana ameaçada, a resignação diante dela. De acordo com a vontade de Sinha Vitória, o nó será preservado: para não se esquecerem de que a cama de lastro de couro se encontra num possível horizonte próximo, e, de algum modo, ela já lhes pertence por direito, como direito universal. O nó será mantido como elemento de memória, como elemento do passado que ainda permanece no presente, que ainda não foi superado.

A consciência de que existe um passado e um presente, de que, junto com a passagem dessas duas esferas temporais operam-se também mudanças materiais, sociais e afetivas, esta autoconsciência do desenvolvimento da sociedade é central para que as personagens e, no limite, os leitores se mobilizem na direção da superação das barreiras objetivas. Fabiano e Sinha Vitória suspeitam, agora, de que a ordem natural precisa ser superada. Percebem que os seres humanos merecem ser libertados de seus laços puramente naturais, de que as necessidades humanas devem ser gradativamente realizadas, satisfeitas. Sinha Vitória e Fabiano também são gente. "Dormiam naquilo, tinham se acostumado, mas seria mais agradável dormirem numa cama de lastro de couro, como outras pessoas". (VS, p. 77) As varas eram retiradas da catinga e, sem qualquer alteração por trabalho especializado, se convertiam numa cama. "Seu Tomás tinha uma cama de verdade, feita pelo carpinteiro, um estrado de sucupira alisado a enxó, com as juntas abertas a formão, tudo embutido direito, e um couro cru por cima, bem esticado e bem 
pregado." (VS, p. 83) Homens como Fabiano e Sinha Vitória devem tomar posse das terras (e das escolas etc.) que cultivam, "e ele, Fabiano, seria o vaqueiro, para bem dizer seria o dono daquele mundo" (VS, p. 51). A produção das riquezas necessárias estaria nas mãos daqueles que desejam viver numa vida renovada.

A família vive condenada entre a as forças naturais hostis à vida humana e aquelas normas sociais possíveis, mas que se revelavam sempre opressivas. As forças hostis da natureza e a injustiça da ordem social estabelecida se impunham, imperdoáveis e de modo determinante, na vida e nas atitudes dos retirantes da novela. Mas há na vida (e a arte os revela) sempre espaços dos quais os homens espreitam a liberdade. Na narrativa, as personagens imaginam-se levando vida de gente. O vaqueiro - estabelecido na fazenda para criar o gado alheio ("o patrão aceitara-o, entregara-lhe as marcas de ferro") expressa, num breve solilóquio, duas posições opostas em relação à sua condição humana. Ele as verbaliza no seguinte contexto:

Pisou com firmeza no chão gretado, puxou a faca de ponta, esgaravatou as unhas sujas. Tirou do aió um pedaço de fumo, pisou-o, fez um cigarro com palha de milho, acendeu-o ao binga, pôs-se a fumar arregalado.

- Fabiano, você é um bicho, exclamou em voz alta.

Conteve-se, (...). E, pensando bem, êle não era homem: era apenas um cabra ocupado em guardar coisas dos outros. Vermelho, queimado, tinha os olhos azuis, a barba e os cabelos ruivos; mas como vivia em terra alheia, cuidava de animais alheios, descobria-se, encolhia-se na presença dos brancos e julgava-se cabra.

Olhou em torno, com receio de que, fora os meninos, alguém tivesse percebido a frase imprudente. Corrigiu-a, murmurando:

- Você é um bicho, Fabiano.

Isto para ele era motivo de orgulho. Sim senhor, um bicho, capaz de vencer dificuldades.

Chegara naquela situação medonha - e ali estava, forte, até gordo, fumando o seu cigarro de palha.

- Um bicho, Fabiano. (VS, pp. 53-54)

Há aqui uma contradição representativa para a posição dos personagens diante da perspectiva emancipadora. Fabiano é levado, num primeiro momento - num impulso de euforia por atingir êxito provisório, a expressar sua felicidade. Enfim, reflete, "Eram todos felizes..." (VS, p. 50). Mas reconhece que essa não era uma imagem verdadeira de si, a de ser um homem, pois a quase totalidade da sua vida se devia à sua força e resistência física, logo, à condição de bicho ${ }^{4}$, o que lhe permitiu sobreviver, ter trazido a sua família em segurança até mais esta paragem. Enxergando seu heroísmo como chefe de família, busca entender as vantagens da condição de forte; daí reafirmar a sua convicção: "Um bicho,

\footnotetext{
${ }^{4}$ De acordo com Zenir Campos Reis, o bicho, diferentemente da rês, que é animal domesticado para o abate, é usado aqui simbolicamente como ser que tem a capacidade física de resistir às adversidades e intempéries do mundo natural. (REIS, 1991)
} 
Fabiano". Mais adiante, entretanto, reconhece a sua verdadeira condição no mundo: "Entristeceu. Considerar-se plantado em terra alheia! Engano. A sina dele era correr mundo, andar para cima e para baixo, à toa, como judeu errante. Um vagabundo empurrado pela seca. Achava-se ali de passagem, era hóspede." (VS, p. 54) Mas é fundamental notarmos que esse homem, condenado a empenhar toda a sua existência e todas as suas forças em resistir às adversidades naturais, teve, por um breve instante, o desejo e a imagem do homem livre, membro do mundo social, com direito ao mundo dos homens, civilizado e seguro. É o que se observa ainda no mesmo capítulo. Estava condenado, pois o mundo social não se abria para ele, não havia sido produzido para ele, estava dele alienado. "Fabiano, uma coisa da fazenda, um traste, seria despedido quando menos esperasse. Ao ser contratado, recebera o cavalo de fábrica, perneiras, gibão, guarda-peito e sapatões de couro cru, mas ao sair, largaria tudo ao vaqueiro que o substituísse." (VS, p. 59). O destino estava traçado para Fabiano e os seus. Era "doidice" de Sinha Vitória querer possuir uma cama. "Cambembes podiam ter luxo?" Fabiano conclui: "Qualquer dia o patrão os botaria fora, e eles ganhariam o mundo, sem rumo, nem teriam meio de conduzir os cacarecos. Viviam de trouxa amarrada, dormiriam bem debaixo de um pau." (VS, p. 59). As observações de Fabiano o levam, objetivamente, a não enxergar saídas para os limites naturais a que estão condenados. Mas jamais ele perderia a crença em tempos futuros melhores.

Era uma sorte ruim, mas Fabiano desejava brigar com ela, sentir-se com força para brigar com ela e vencê-la. Não queria morrer. Estava escondido no mato como tatu. Duro, lerdo como tatu. Mas um dia sairia da toca, andaria com a cabeça levantada, seria homem.

- Um homem, Fabiano. (VS, pp. 59-60)

Dizia Hegel que "a liberdade é apenas o conhecimento da necessidade". Mas ela se realiza verdadeiramente apenas quando as necessidades são sempre, concretamente, renovadas, criadas e atendidas; assim a liberdade se realiza em sentido global e no sentido do processo histórico-social. O reino da liberdade é a realização criadora das necessidades humanas, sempre renovadas. Sinha Vitória reflete: "Por que [Fabiano] não tinha removido aquela vara incômoda? Suspirou. Não conseguiam tomar resolução. Paciência. Era melhor esquecer o nó e pensar numa cama igual à de Seu Tomás da bolandeira" (VS, p. 83). O projeto da cama nova não abandona os pensamentos da mulher de vaqueiro. "Se vendesse as galinhas e a marrã? (...) Ergueu-se, foi à camarinha procurar qualquer coisa, voltou esquecida. Onde tinha a cabeça?" (VS, p. 83). Mas para Sinha Vitória, a cama não pode ser um mero projeto, como é para Fabiano. Prefere manter a vara com o nó a passar a vida dormindo em cama de vara, contentando-se com uma cama de couro imaginária, como Fabiano: 
Sentou-se na janela baixa da cozinha, desgostosa. Venderia as galinhas e a marrã, deixaria de comprar querosene. Inútil consultar Fabiano, que sempre se entusiasmava, arrumava projetos. Esfriava logo - e ela franzia a testa, espantada, certa de que o marido se satisfazia com a ideia de possuir uma cama. Sinha vitória desejava uma cama real, de couro e sucupira, igual à de Seu Tomás da bolandeira. (VS, p. 84)

Entre essas duas personagens há diferenças importantes, há uma defasagem tensa, produtiva do ponto de vista artístico: só ela alcança, objetivamente, a necessidade e a possibilidade o projeto da cama. Ele "se satisfaz com a idéia de possuir uma cama." Ou seja, para ele, a necessidade da cama pode ser resolvida abstratamente.

É desse movimento dialético que a realidade contém que o artista precisa tomar conhecimento. É imprescindível à sobrevivência da arte que deseja ser fiel à trajetória dos homens em sua luta emancipadora que ela seja capaz de descobrir as forças essenciais que movem as atitudes e os destinos humanos. Diz Lukács em "Arte livre ou arte dirigida?":

Não depende dos artistas que haja ou não crise no mundo. Mas depende deles saber utilizar essa crise de maneira fecunda para eles mesmos e para a arte. Depende dos artistas mostrar quanto de liberdade eles são capazes de encontrar na inelutável necessidade e em que medida são capazes de utilizá-la livremente e de modo fecundo para eles mesmos e para a arte. (LUKÁCS, 2010, p. 284)

O processo artístico, ao fazer com que o leitor assimile as carências implícitas do mundo representado e nele é capaz de identificar as suas próprias carências, as do seu próprio mundo, gera também o seu revés. Quando essas carências são reconhecidas pelo leitor, elas implicam, por sua vez, o seu oposto dialético, a necessidade e possibilidade de superação. $O$ mundo dos homens encontra-se enfeitiçado, como se forças mágicas fossem responsáveis pelos destinos individuais. O indivíduo está paralisado em seu cárcere privado, solitário, condenado; mas a obra de arte realista quebra o fetiche da imutabilidade. É necessário - e possível - superar barreiras objetivas, menores e maiores, a partir de existências humanas singulares.

\section{Referências}

ABDALA JUNIOR, Benjamin. "Práxis artística e utopia concreta em Graciliano Ramos". In: Novos Rumos. São Paulo, n. 29, pp. 74-87, 1999. 
BUENO, Luís. "A presença do amor em Vidas secas". In: Teresa Revista de literatura brasileira [16]; São Paulo, 2015, pp. 135-150.

CANDIDO, Antonio. "Ficção e confissão". In: Ficção e confissão. Rio de Janeiro: Ed. 34, 1999.

. "A personagem do romance". In: Et alii. $A$ personagem de ficção. São

Paulo: Perspectiva, 1976.

. CANDIDO, Antonio. "Literatura e subdesenvolvimento". In: Educação pela noite e outros ensaios. São Paulo: Ática, 1989.

COUTINHO, Carlos Nelson. Literatura e humanismo. Rio de Janeiro: Paz e Terra, 1967.

GARBÚGLIO, José Carlos et alii. Graciliano Ramos. São Paulo: Ática, 1987.

GOLDMANN, Lucien. A sociologia do romance. Rio de Janeiro: Paz e Terra, 1976.

LUKÁCS, Georg. Der russische Realismus in der Weltliteratur. Berlin: Aufbau-Verlag, 1949.

. Realismo crítico hoje. Brasília: Coordenada-Editora de Brasília, 1969.

. Marxismo e teoria da literatura. São Paulo: Expressão Popular, 2010.

MARX, Karl, ENGELS, Friedrich. Cultura, arte e literatura: textos escolhidos. São Paulo: Expressão Popular, 2010.

NETTO, José Paulo. Georg Lukács: o guerreiro sem repouso. São Paulo: Brasiliense, 1983. RAMOS, Graciliano. Vidas secas. São Paulo: Martins, 1969.

. "O fator econômico no romance brasileiro". In: Linhas Tortas. São Paulo: Martins, 1971.

. “O romance de Jorge Amado". In: Linhas Tortas, São Paulo: Martins, 1971.

. "A decadência do romance brasileiro". In: Garranchos: textos inéditos de Graciliano Ramos. (Organização de Thiago Mio Salla). Rio de Janeiro/São Paulo: Record, 2012.

REIS, Zenir Campos. "Tempos futuros". In: Revista do Instituto de Estudos Brasileiros. São Paulo, n. 35, pp. 69-92, 1993. 